Jpn. J. Cancer Res. 81, 289-297, March 1990

\title{
Chemo-radioresistance of Small Cell Lung Cancer Cell Lines Derived from Untreated Primary Tumors Obtained by Diagnostic Bronchofiberscopy
}

\author{
Yoshiro Tanio,, ${ }^{1,5}$ Masatoshi Watanabe, ${ }^{1}$ Tamotsu Inoue, ${ }^{1}$ Ichiro Kawase, ${ }^{1}$ Takuma \\ Shirasaka, ${ }^{1}$ Toshiyuki Ikeda, ${ }^{1}$ Hideki Hara, ${ }^{1}$ Tomiya Masuno, ${ }^{1}$ Shin'ichi Saito, ${ }^{1}$ Kiyoshi \\ Kawano, ${ }^{2}$ Hajime Kitamura, ${ }^{2}$ Kaoru Kubota, ${ }^{3}$ Nagahisa Kodama, ${ }^{3}$ Masaaki Kawahara, ${ }^{3}$ \\ Mitsunori Sakatani, ${ }^{3}$ Kiyoyuki Furuse, ${ }^{3}$ Satoru Yamamoto ${ }^{4}$ and Susumu Kishimoto ${ }^{1}$ \\ ${ }^{I}$ Third Department of Internal Medicine and ${ }^{2}$ Department of Pathology, Osaka University Medical \\ School, 1-1-50, Fukushima, Fukushima-ku, Osaka 553, and ${ }^{3}$ Department of Internal Medicine and \\ ${ }^{4}$ Department of Pathology, National Kinki-Chuo Hospital, Sakai 591
}

\begin{abstract}
New cell lines of small cell lung cancer (SCLC) were established from specimens of untreated primary tumors biopsied by diagnostic bronchofiberscopy. The advantage of this method was ease of obtaining specimens from lung tumors. Establishment of cell lines was successful with 4 of 13 specimens (30\%). Clinical responses of the tumors showed considerable variation, but were well correlated with the in vitro sensitivity of the respective cell lines to chemotherapeutic drugs and irradiation. One of the cell lines was resistant to all drugs tested and irradiation, while another was sensitive to all of them. Although the acquired resistance of SCLC is the biggest problem in treatment, the natural resistance to therapy is another significant problem. Either acquired or natural, resistance mechanisms of SCLC may be elucidated by the use of such cell lines derived from untreated tumors. This method and these SCLC cell lines are expected to be useful for the serial study of biologic and genetic changes of untreated and pre-treated tumors, or primary and secondary tumors.
\end{abstract}

Key words: Small cell lung cancer - Cell lines - Untreated primary tumors - Bronchofiberscopic biopsy - Clonogenic assay

A number of cell lines of small cell lung cancer (SCLC) ${ }^{6}$ have been established since Oboshi's earliest report of an SCLC cell line in $1971^{1)}$ and their biologic and genetic characteristics have been elucidated. ${ }^{2-14}$ ) However, almost all cell lines of SCLC were derived from metastasized lesions or previously treated tumors because SCLC is clinically malignant and few cases are operable at diagnosis. It is widely accepted that metastatic tumor cells are quite different from primary tumor cells in biologic behavior, and drug and radiation sensitivity, and tumor cells may also change after therapy. ${ }^{14-18)}$

We have been trying to establish new SCLC cell lines from untreated primary tumors biopsied by diagnostic bronchofiberscopy to investigate the mechanisms of their resistance to chemo-radiotherapy. Several investigators have derived SCLC cell lines from specimens biopsied through a bronchoscope but their success rate was very low. ${ }^{2,1)}$ Furthermore such cell lines have not been sufficiently analyzed for chemo-radiosensitivity in relation to clinical response. So there was no proof that they were truly representative of the original tumors which

\footnotetext{
${ }^{5}$ To whom correspondence should be addressed.

${ }^{6}$ Abbreviations used are: SCLC, small cell lung cancer; NC, no change; $C R$, complete response; $P R$, partial response; $P D$, progressive disease; MoAb, monoclonal antibody.
}

finally killed their hosts. We describe in this report how to establish SCLC cell lines from untreated primary tumors and a good correlation between clinical responses of tumors and in vitro chemo-radiosensitivity of the respective cell lines.

\section{MATERIALS AND METHODS}

Patients Patients were staged on the basis of routine examinations and classified as having limited disease (LD) when it was confined to one hemithorax and bilateral hilar, mediastinal and supraclavicular lymph nodes without pleural effusion, or extensive disease (ED) which extended beyond the definition for LD. Chemotherapy for SCLC consisted of cyclophosphamide (CTX, 800 $\mathrm{mg} / \mathrm{m}^{2}$ ), adriamycin (ADM, $50 \mathrm{mg} / \mathrm{m}^{2}$ ) and vincristine (VCR, $1.4 \mathrm{mg} / \mathrm{m}^{2}$ ) for one cycle, and cisplatin (CDDP, $80 \mathrm{mg} / \mathrm{m}^{2}$ ) and etoposide (VP-16, $100 \mathrm{mg} / \mathrm{m}^{2} \times 3$ ) for another cycle. Radiotherapy for primary tumors and mediastinum was performed for consolidation or when chemotherapy was unsuccessful. Total dosage of irradiation differed individually. Patients $\# 1$ and $\# 2$ were treated with $80 \mathrm{~Gy}$, and Patient $\# 4$ was treated with $56 \mathrm{~Gy}$. Patient $\# 1$ achieved complete remission, but 14 months later the tumor regrew at the same site. Patient $\# 2$ died of progressive lung cancer about 32 weeks after the first intensive chemotherapy. Patient $\# 3$ died before starting 
therapy, and Patient \#4 achieved partial remission following radiotherapy but finally died of the progressive tumor after about 41 weeks. Performance status was 1 for Patients $\# 1, \# 2$ and $\# 4$, and 2 for $\# 3$ by World Health Organization criteria. Although the number of patients was small, the overall response rate to the chemoradiotherapy was $7 / 12(58 \%): 5 / 6(83 \%)$ for LD cases and $2 / 6(33 \%)$ for ED cases.

Tumor specimens Bronchofiberscopic biopsy was performed during staging procedures. Tumor specimens were obtained from 20 patients with a presumptive diagnosis of SCLC during the period from August, 1986 to October, 1987. Histopathological examination revealed that 5 were non-SCLC and 13 were SCLC, but 2 were cytopathologically negative although they were diagnosed as SCLC on the basis of another biopsy. A flexible fiberoptic bronchoscope (Olympus BF B10, Tokyo) was transorally introduced without general anesthesia and several pieces of visible endobronchial tumors were biopsied with crocodile-forceps. Some of the specimens were transferred to the surgical pathology service for histological diagnosis. Others were put into cold phosphatebuffered saline $\left(0.68 \% \mathrm{NaCl} ; 10.4 \mathrm{mM} \mathrm{Na} 2 \mathrm{HPO}_{4} ; 3.2\right.$ $\mathrm{m} M \mathrm{KH}_{2} \mathrm{PO}_{4} ; \mathrm{pH} 7.2$ ) supplemented with penicillin (PC, $500 \mathrm{U} / \mathrm{ml}$ ), streptomycin (SM, $500 \mu \mathrm{g} / \mathrm{ml}$ ) and amphotericin B $(2 \mu \mathrm{g} / \mathrm{ml})$.

Culture methods After being kept on ice for 0.5 to $1 \mathrm{~h}$, specimens were centrifuged and cut into small pieces with ophthalmic scissors. They were placed in 6-well culture plates (Terumo Co., Tokyo) containing RPMI1640 (Nissui Pharmaceutical Co., Tokyo) supplemented with PC (100 U/ml), SM $(100 \mu \mathrm{g} / \mathrm{ml}), 2 \mathrm{~m} M_{\text {L-gluta- }}$ mine (L-Gln) and $10 \%$ heat-inactivated fetal bovine serum (FBS, General Scientific Laboratories, Los Angeles, CA), which was designated as complete medium. Some cultures were initiated in RPMI-1640 supplemented with PC $(100 \mathrm{U} / \mathrm{ml})$, SM $(100 \mu \mathrm{g} / \mathrm{ml})$, $\mathrm{L}-\mathrm{Gln}(2 \mathrm{~m} M)$, hydrocortisone $(10 \mathrm{n} M)$, insulin $(5 \mu \mathrm{g} /$ $\mathrm{ml}$, Shimizu Pharmaceutical Co., Osaka), transferrin $(100 \mu \mathrm{g} / \mathrm{ml}), 17 \beta$-estradiol $(10 \mathrm{nM})$, and sodium selenite (30 $\mathrm{n} M$ ), which was designated as HITES medium, ${ }^{4,5}$ ) and were later switched to HITES medium supplemented with 5\% FBS. Hydrocortisone, transferrin, $17 \beta$-estradiol and sodium selenite were obtained from Sigma Chemical Co., St. Louis, MO. The plates were incubated in a humidified atmosphere of $5 \% \mathrm{CO}_{2}: 95 \%$ air at $37^{\circ} \mathrm{C}$. Every 1 to 2 weeks half of the medium was changed without aspirating the floating cells. Cells were expanded when they began to proliferate well, and continuous cell lines were established after 3 to 19 months. These cell lines were free of mycoplasma contamination as tested by Bacto PPLO Agar (Difco Laboratories, Datroit, MI). Histopathology Biopsied specimens were fixed in $10 \%$ formalin, and embedded in paraffin. Sections were stained with hematoxylin-eosin, alcian blue-PAS and by the Grimelius method for argyrophil granules for conventional light microsocpic observation. Samples for electron microscopy were fixed in $2 \%$ glutaraldehyde and $1 \%$ osmium tetroxide, and embedded in epoxy resin. Ultrathin sections were double-stained with uranyl acetate and lead citrate for examination.

Animals Male BALB/c nude $(n u / n u)$ mice were purchased from Shizuoka Agricultural Cooperative for Experimental Animals, Hamamatsu. Mice were used at 8 to 10 weeks of age.

Tumorigenicity in nude mice Tumor cells suspended in $50 \mu 1$ buffer were injected intracranially into athymic nude mice. When the mice became ataxic, they were killed and the brains were removed for histological examination.

Doubling time As SCLC cell lines were densely packed and hard to break up into single cells by conventional enzyme treatment, doubling time was determined by protein measurement using a modified Lowry method. ${ }^{19)}$ Biochemical markers Cell homogenates were used for measurement of neuron-specific enolase (NSE) and brain isozyme of creatine kinase (CK-BB). SRL Company (Tokyo) measured NSE by radioimmunoassay ${ }^{20}$ and CK-BB by cellulose acetate electrophoresis. ${ }^{21)}$ Gastrinreleasing peptide (GRP) was extracted by boiling the cell pellet and measured by Drs. Miyake and Yamaguchi (National Cancer Center Research Institute, Tokyo) according to the reported method. ${ }^{22)}$

Enzyme treatment For clonogenic assay, densely packed cell lines were treated with $0.01 \%$ DNase I (Sigma Chemical Co.) and $0.05 \%$ collagenase S-1 (Nitta Gelatine Co., Osaka) for $1 \mathrm{~h}$ at $37^{\circ} \mathrm{C}$. Trypsin was not used as it was toxic to SCLC cell lines. After washing with complete medium 3 times, cells were suspended in HITES medium supplemented with $5 \%$ FBS and again incubated in a humidified atmosphere of $5 \% \mathrm{CO}_{2}: 95 \%$ air at $37^{\circ} \mathrm{C}$ overnight. On the day of assay, cells were suspended in fresh medium and gently pipetted. Cell suspension in a plastic tube was kept in an upright position for several minutes and a portion of single cells was used for the assays.

Southern hybridization Cellular DNAs were extracted from the SCLC cell lines, human placenta, another SCLC cell line (H69), and human promyelocytic leukemia cell line (HL60). H69 and HL60 were kindly given by Dr. Shimosato and Dr. Kiyotaki, respectively. The amplification of myc family oncogenes was analyzed by the previously described methods ${ }^{23}$ with slight modifications. In brief, $10 \mu \mathrm{g}$ of cellular DNA was digested with EcoRI (Wako, Osaka) and separated by electrophoresis on a $0.7 \%$ agarose gel. After denaturing, DNA was transferred to nylon membrane (Pall, East Hills, NY) according to Southern's procedures. ${ }^{24)}$ The blots were baked, hybridized to ${ }^{32} \mathrm{P}$-labeled probes at $42^{\circ} \mathrm{C}$ under 
stringent conditions (50\% formamide, $5 \times \mathrm{SSC}$ ), and washed first in $2 \times \mathrm{SSC}$ and $0.1 \%$ SDS for $5 \mathrm{~min}$ at room temperature and then in $0.1 \times$ SSC and $0.1 \%$ SDS for 15 min at $50^{\circ} \mathrm{C}$. Autoradiography was performed on XAR5 films for $8 \mathrm{~h}$ to 1 week at $-70^{\circ} \mathrm{C}$. Rehybridization with a second probe was performed after washing in $50 \%$ formamide and $10 \mathrm{mM} \mathrm{NaH} \mathrm{PO}_{4}(\mathrm{pH} \mathrm{6.5)}$ for $1 \mathrm{~h}$ at $65^{\circ} \mathrm{C}$, and in $2 \times \mathrm{SSC}$ and $0.1 \% \mathrm{SDS}$ for $15 \mathrm{~min}$ at room temperature.

Probes DNA probes used in this study included a 1.5 kbp SacI fragment for c- $m y c{ }^{25)}$ a $2.0 \mathrm{kbp} E c o$ RI fragment for $\mathrm{N}-m y c{ }^{26)}$ a $1.8 \mathrm{kbp} S m a \mathrm{I}-E c o \mathrm{RI}$ fragment for L- $m y c,{ }^{27)}$ and a $3.3 \mathrm{kbp} E c o \mathrm{RI}-H i n d I I I$ fragment for immunoglobulin gene $\mathrm{J}_{\mathrm{H}}{ }^{28)}$ All probes were labeled with ${ }^{32} \mathrm{P}$ using multiprime DNA labeling systems (Amersham, Buckinghamshire, England). Three myc oncogenes were gifts from the Japanese Cancer Research Resources Bank. $\mathbf{J}_{\mathrm{H}}$ was kindly given by Dr. Ogawa.

Clonogenic assay in soft agar Tumor cells were plated in $0.3 \%$ Noble agar (DIFCO Laboratories) on a support layer of $0.5 \%$ agar as described by Hamburger and Salmon. ${ }^{29)}$ Colonies containing more than 40 cells were counted 2 to 4 weeks after plating. Colony-forming efficiency (CFE) was calculated by using the following formula:

$$
\frac{\text { colonies }}{\text { viable cells plated }} \times 100(\%) \text {. }
$$

Chemo-radiosensitivity assay was also carried out by a slight modification of Salmon's method. ${ }^{30)}$ In drug sensitivity tests, cells $\left(10^{5} / \mathrm{ml}\right)$ were incubated with drugs at the achievable peak plasma concentration, or 1- or 2-log dilutions of that concentration for $1 \mathrm{~h}$ at $37^{\circ} \mathrm{C}$. Since CTX is a masked form, 4-hydroperoxy-cyclophosphamide (4-OOH-CTX) was used for in vitro assay. Other drugs were the same as those which were given to patients. In radiation sensitivity tests, cells $\left(2 \times 10^{5} / \mathrm{ml}\right)$ were irradiated at room temperature with a linear accelerator. After the treatment with drugs or irradiation, cells were washed with RPMI-1640 3 times and plated in HITES medium supplemented with $0.3 \%$ agar and $10 \%$ FBS on a support layer of $0.5 \%$ agar. All drug concentrations and irradiation doses were tested in triplicate.

Enzyme-linked immunosorbent assay (ELISA) Anti SCLC monoclonal antibody (MoAb) was raised by immunizing BALB/c mice with one of our SCLC cell lines (OS1). This MoAb specifically reacted with SCLC and not with non-SCLC by ELISA and immunostaining methods. It also reacted with neuroblastoma cell lines and neuroendocrine organs such as brain, spinal cord and adrenal medulla, but not with adrenal cortex, thyroid follicles, cardiac muscles, liver, spleen, kidney and digestive organs. Therefore, this MoAb seemed to belong to cluster 1 according to the first international workshop on
SCLC antigens. ${ }^{31)}$ Competitive inhibition assay, however, showed that the MoAb reacted with a different epitope from those identified by MOC-1 (Bio-Science Products, Emmenbrucke, Switzerland) and NKH-1 (Coulter Immunology, Hialeah, FL) (in preparation). Using this MoAb, the cell lines were checked by ELISA, as described elsewhere. ${ }^{32)}$

\section{RESULTS}

Characteristics of biopsied SCLC specimens Four SCLC cell lines were established from 13 pathologically positive specimens $(30 \%)$. The characteristics of the original tumors are summarized in Table 1 . Ease of establishment was not correlated with patient's age or sex, disease extent, primary tumor site or clinical response to chemoradiotherapy.

Morphological characteristics of the cell lines As its doubling time was quite long (about 10 days), OS4 was not fully characterized. However, OS4 grew floating as densely packed spherical aggregates and was stained with our MoAb to SCLC. It also had elevated GRP (870 $\mathrm{pg} / \mathrm{mg}$ protein). Cell lines other than OS4 were studied more extensively (Table II) and the histological appearances of the original tumors in the bronchus are shown in Fig. 1. Although some crushing artifacts were observed in the biopsy specimens, they were clearly diagnosed as SCLC. The established 3 cell lines have continued to grow for more than 2 years. OS1 grew as floating aggregates, and was quite pleomorphic and heterogeneous in size (Fig. 2A). OS2 also grew as floating aggregates and the individual cells were lymphocyte-like (Fig. 2B). On the other hand, OS3 was loosely adherent to culture flasks (Fig. 2C). The former type was classified as type 2 and the latter type as type 4 according to Carney's classification. ${ }^{7)}$ Two cell lines except OS2 had no identifiable dense core granules, although some similar granules were seen. Tumors were formed in the cranial cavity of nude mice by the inoculation of each cell line.

Biologic and biochemical characteristics As shown in Table II, doubling time was quite different among these 3 cell lines: 3.5 days for OS1, 5 days for OS2 and 2 days for OS3. The doubling time influenced the CFE. OS3, whose doubling time was the shortest among the 3 cell lines, formed about 12 times as many colonies as OS2 after 2 weeks. Counting colonies was carried out when the colonies were easily detectable. It took 3,4 and 2 weeks for OS1, OS2 and OS3 respectively to form detectable colonies, when equal numbers of cells were plated on the soft agar.

Three biochemical markers, characteristic of SCLC, were measured. NSE was elevated in all 3 cell lines but CK-BB was low in OS1. GRP was elevated only in OS2. Using SCLC-specific MoAb, all 3 cell lines were posi- 
Table I. Characteristics of SCLC Specimens Biopsied by Diagnostic Bronchofiberscopy

\begin{tabular}{cccccccc}
\hline $\begin{array}{c}\text { Patient } \\
\text { No. }\end{array}$ & Age & Sex & $\begin{array}{c}\text { Prior } \\
\text { therapy }\end{array}$ & $\begin{array}{c}\text { Disease } \\
\text { extent }\end{array}$ & $\begin{array}{c}\text { Tumor } \\
\text { site }\end{array}$ & $\begin{array}{c}\text { Period from biopsy } \\
\text { to establishment } \\
\text { (months) }\end{array}$ & $\begin{array}{c}\text { Clinical } \\
\text { response }\end{array}$ \\
\hline 1 & 47 & F & - & LD & LUB & 10 & CR \\
2 & 50 & M & - & LD & LUB & 9 & NC \\
3 & 69 & M & - & ED & RUB & 19 & PD \\
4 & 72 & M & - & LD & LUB & 3 & PR \\
\hline
\end{tabular}

F, female; M, male; LD, limited disease; ED, extensive disease; LUB, left upper bronchus; RUB, right upper bronchus; $\mathrm{CR}$, complete response; $\mathrm{PR}$, partial response; NC, no change; $\mathrm{PD}$, progressive disease.

Table II. Characteristics of SCLC Cell Lines Derived from Untreated Primary Tumors Biopsied by Bronchofiberscopy

\begin{tabular}{|c|c|c|c|}
\hline & \multicolumn{3}{|c|}{ Cell line } \\
\hline & OS1 & OS2 & OS3 \\
\hline Patient No. & 2 & 1 & 4 \\
\hline Culture duration & $8 / 28 / 86 \sim$ & $8 / 21 / 86 \sim$ & $7 / 28 / 87 \sim$ \\
\hline \multirow[t]{2}{*}{ Morphology in vitro } & densely packed & densely packed & aggregates \\
\hline & $\begin{array}{l}\text { floating aggregates } \\
\text { (type 2) }\end{array}$ & $\begin{array}{l}\text { floating aggregates } \\
\text { (type 2) }\end{array}$ & $\begin{array}{l}\text { attached to substrate } \\
\text { (type 4) }\end{array}$ \\
\hline Dense core granules & - & + & - \\
\hline Tumorigenicity & + & + & + \\
\hline Doubling time $(h)$ & 86 & 121 & 49 \\
\hline $\mathrm{CFE}(\%)$ & 4.3 & 0.4 & 5.7 \\
\hline NSE (ng/mg protein) & 2054 & 7442 & 609 \\
\hline CK-BB (U/g protein) & 65 & 3645 & 1571 \\
\hline GRP (pg/mg protein) & unmeasurable & 5300 & unmeasurable \\
\hline Reactivity to a $\mathrm{MoAb}$ & + & + & + \\
\hline $\begin{array}{l}\text { Oncogene amplification } \\
\left(c-, N_{-}, \text {L-myc) }\right.\end{array}$ & $\mathrm{N}-m y c$ & - & - \\
\hline $3 \mathrm{p}$ deletion ${ }^{a)}$ & + & + & NT \\
\hline
\end{tabular}

a) S. Hosoe and B. Zbar (NCI-FCRF, Frederick, MD); personal communication. NT, not tested.

tively stained in the immunoperoxidase assay and their membrane antigens were also detected by ELISA.

Southern blot analysis Cellular DNAs from the 3 cell lines were analyzed for the amplification of myc family oncogenes (c-, N- and L-myc). Placental DNA was used as a normal control. HL60 and H69 were used as positive controls for the amplification of c-myc $(12.5 \mathrm{~kb} E c o \mathrm{RI}$ fragments $)^{33)}$ and N-myc ( $2 \mathrm{~kb}$ EcoRI fragments), ${ }^{34)}$ respectively. As shown in a blot hybridized with both c-myc and $\mathrm{N}-m y c$ (Fig. 3), the amplification of N-myc was seen in OS1, but both OS2 and OS3 had no amplification of myc oncogenes. L-myc amplification was not observed in any cell line in another blot analysis (data not shown). Immunoglobulin gene $\mathbf{J}_{\mathrm{H}}$ was used as an internal control (data not shown) and also c-myc and $\mathrm{N}$-myc were internal controls for each other, since there was no cell line which had 2 oncogene amplifications.
Loss of heterozygosity on chromosome $3 p$ was seen in OS1 and OS2 by Southern hybrdization (S. Hosoe and B. Zbar, personal communication). OS3 was not analyzed because of the absence of control DNA (Table II).

Based on the above-mentioned results, OS1 and OS3 were thought to be variant types of SCLC and OS2 was a classic type according to Carney's classification, ${ }^{7}$ although they had some intermediate characteristics.

Chemo-radiosensitivity of SCLC cell lines Clonogenic assay was carried out to analyze the sensitivity of SCLC cell lines to chemotherapeutic drugs and irradiation. Although representative data of 3 experiments are shown in Table III, the chemo-radiosensitivities of 3 cell lines were not very different during a half year. Only one drug concentration, which was one-tenth of the peak plasma concentration, is shown in the column of drug sensitivity, but results at other drug concentrations were almost the 

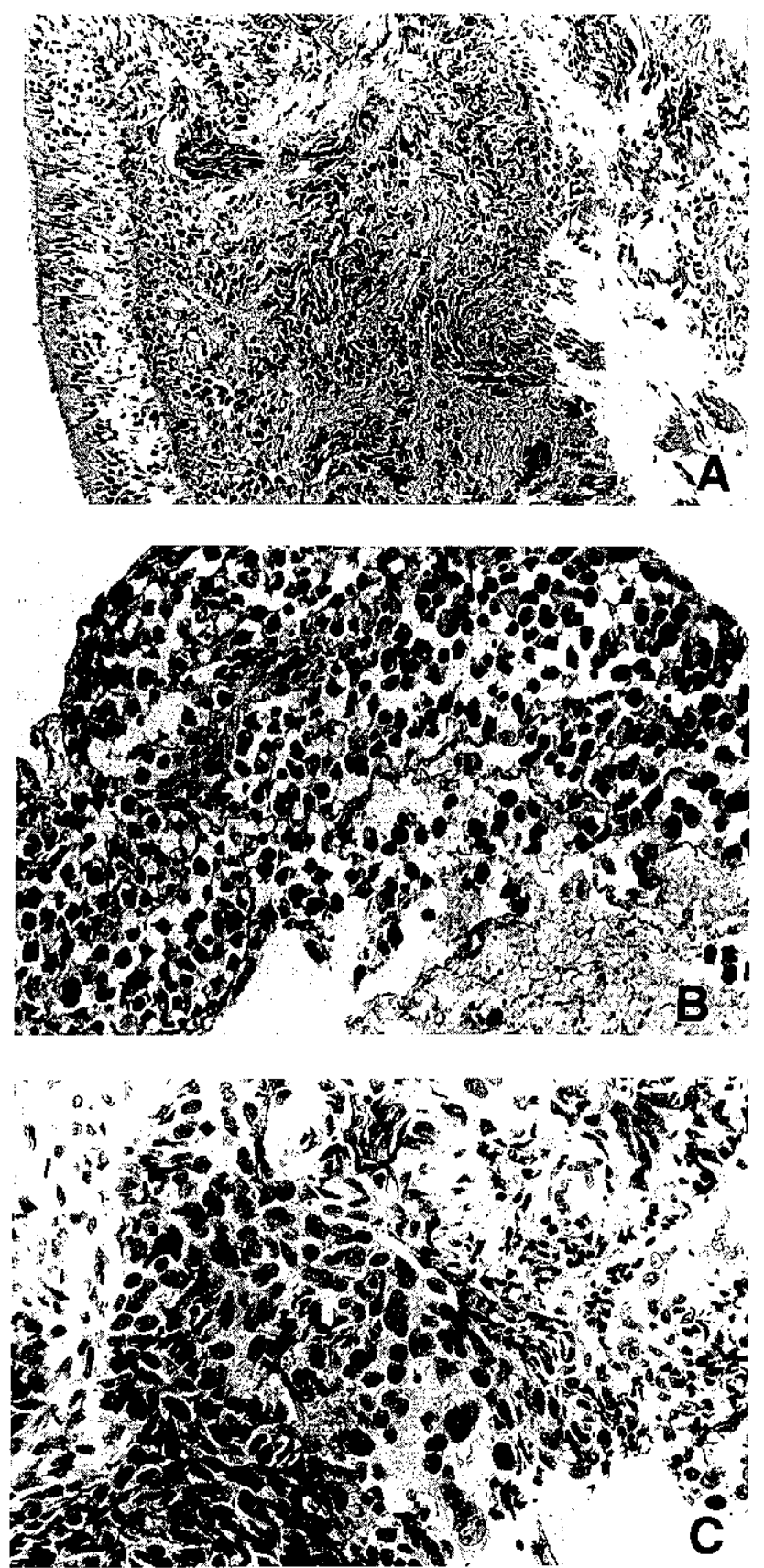

Fig. 1. Histological appearances of the endobronchial tumors of Patients $\# 2$, $\# 1$ and $\# 4$ (hematoxylin-eosin stain). A. Patient $\sharp 2$; Small malignant cells were found infiltrating subepithelial connective tissue of the bronchus in a biopsied specimen, which was diagnosed as oat-cell type of SCLC. OS1 cell line was established from this tumor. B. Patient $\# 1$; Lymphocyte-like cells were infiltrating subepithelial connective tissue of bronchus, which was diagnosed as oat-cell type of SCLC. OS2 cell line was established from this tumor. C. Patient $\$ 4$; Polygonal small cells with keratinization were found in the bronchial epithelium, which was diagnosed as intermediate-cell type of SCLC. OS3 cell line was established from this tumor.
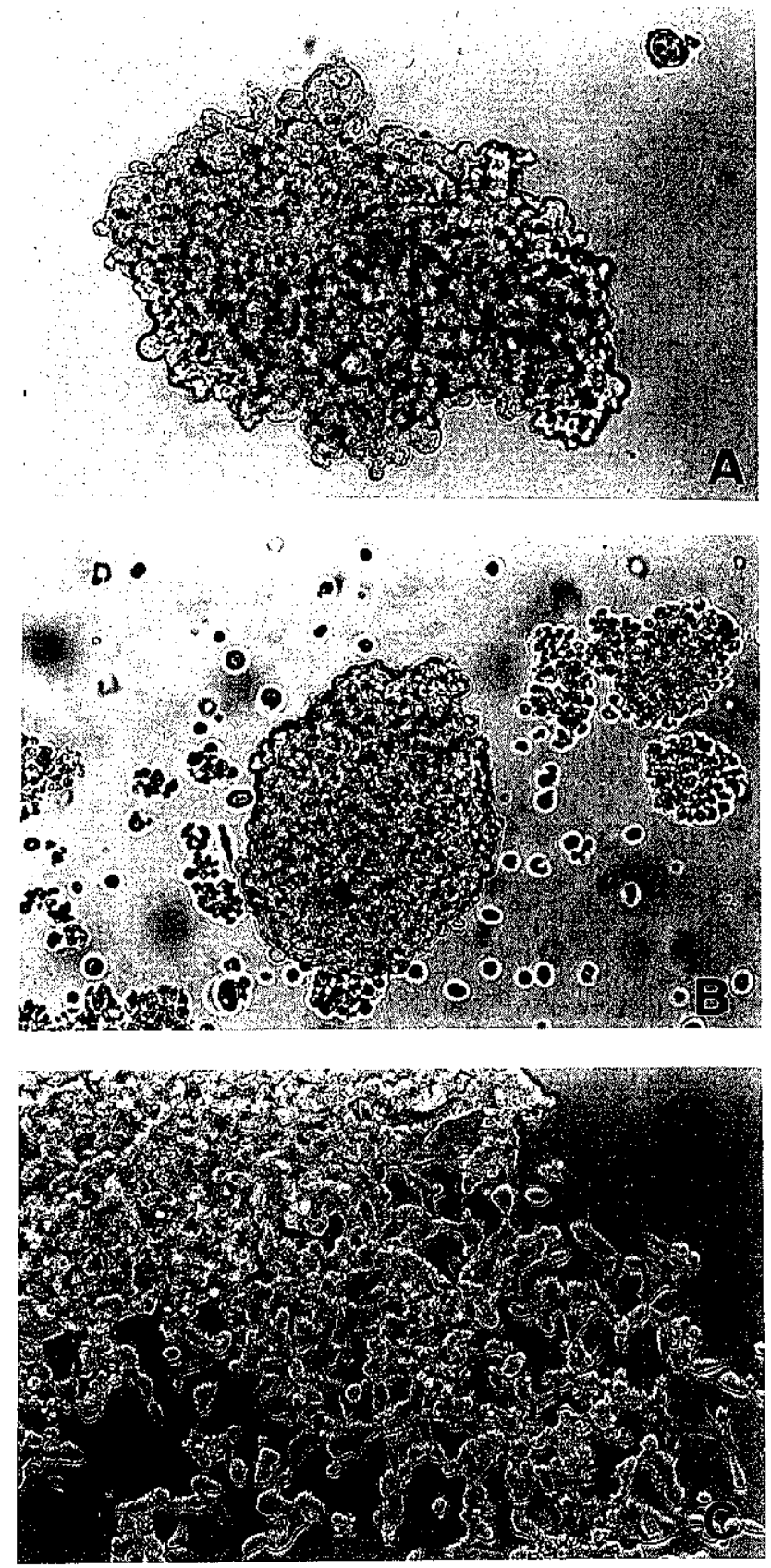

Fig. 2. Culture morphology of SCLC cell lines. A. OS1; Heterogeneous cells are aggregated, floating in the medium. B. OS2; Lymphocyte-like cells are aggregated, floating in the medium. C. OS3; Cells are adherent to the plastic flasks and piled up. Magnifications are as follows: $A, \times 400 ; B, \times 400$; and C, $\times 200$. 


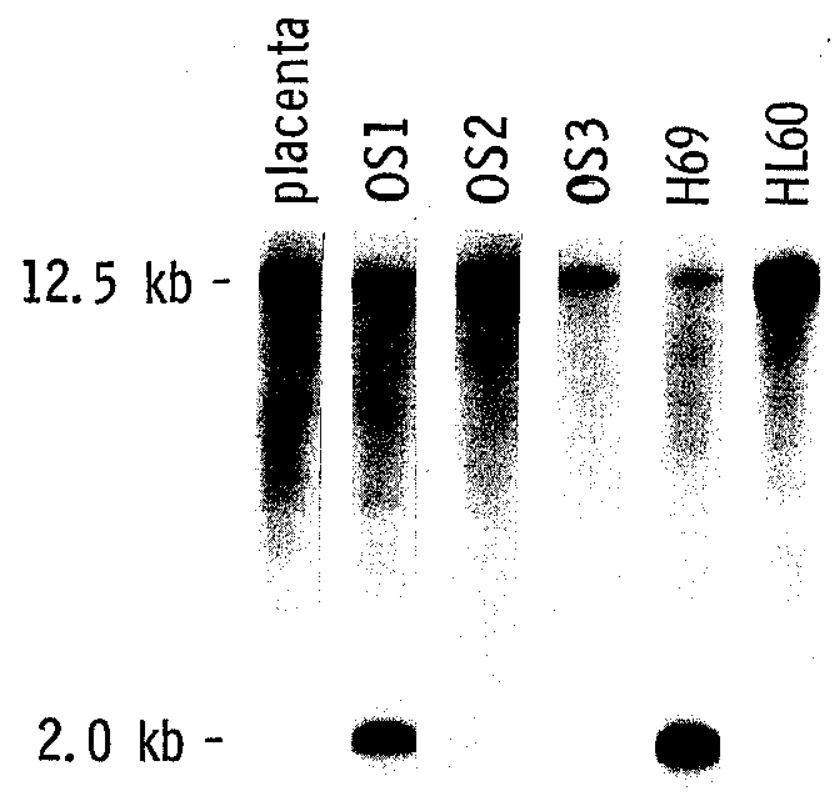

same. The number of clonogenic cells surviving each treatment is given as a mean percentage of the control for 3 dishes: OS1 was resistant to all drugs and irradiation, which was well correlated with the clinical response, NC. Unlike OS1, OS2 was very sensitive to all drugs and irradiation, which also showed a good correlation with the clinical response, CR. On the other hand, OS3 was resistant to drugs but sensitive to irradiation at higher dosage, which again seemed to reflect the clinical response of the tumor (NC followed by PR).

Fig. 3. Southern blot hybridization. Cellular DNAs of SCLC cell lines were digested with EcoRI and hybridized with both $\mathrm{c}-m y c$ and $\mathrm{N}-m y c$ probes. Under stringent conditions, c-myc and $\mathrm{N}$-myc hybridized with $12.5 \mathrm{~kb}$ and $2.0 \mathrm{~kb}$ of EcoRI fragments respectively. Placental DNA was used as a normal control, and HL60 and H69 were positive controls for the amplification of $c-m y c$ and $\mathrm{N}-m y c$, respectively.

Table III. Correlation of Clinical Responses with Clonogenic Assay for SCLC Cell Lines Derived from Untreated Primary Tumors

\begin{tabular}{|c|c|c|c|c|c|c|c|}
\hline \multirow{2}{*}{$\begin{array}{l}\text { Patient } \\
\text { No. }\end{array}$} & \multicolumn{2}{|c|}{ Clinical response $e^{a)}$} & \multirow{2}{*}{$\begin{array}{l}\text { Cell } \\
\text { line }\end{array}$} & \multicolumn{4}{|c|}{ Colony formation $(\%)^{b)}$} \\
\hline & Chemo-Tx & Radio-Tx & & Drug ${ }^{c}$ & & $\begin{array}{l}\text { Radiati } \\
\text { (Gy) }\end{array}$ & \\
\hline \multirow[t]{5}{*}{2} & $\mathrm{NC}$ & $\mathrm{NC}$ & OS1 & 4-OOH-CTX & 116.2 & 2 & 99.7 \\
\hline & & & & ADM & 99.0 & 4 & 66.1 \\
\hline & & & & VCR & 99.7 & 8 & 47.6 \\
\hline & & & & CDDP & 107.6 & & \\
\hline & & & & VP-16 & 98.7 & & \\
\hline \multirow[t]{5}{*}{1} & $\mathrm{CR}$ & $\mathrm{CR}$ & OS2 & 4-OOH-CTX & 23.7 & 2 & 14.5 \\
\hline & & & & ADM & 13.3 & 4 & 14.2 \\
\hline & & & & VCR & 31.2 & 8 & 12.2 \\
\hline & & & & CDDP & 8.5 & & \\
\hline & & & & VP-16 & 13.2 & & \\
\hline \multirow[t]{5}{*}{4} & $\mathrm{NC}$ & PR & OS3 & 4-OOH-CTX & 96.0 & 2 & 67.8 \\
\hline & & & & $\mathrm{ADM}$ & 106.0 & 4 & 14.1 \\
\hline & & & & VCR & 121.6 & 8 & 9.4 \\
\hline & & & & CDDP & 124.2 & & \\
\hline & & & & VP-16 & 85.2 & & \\
\hline
\end{tabular}

a) Three to four cycles of chemotherapy, which consisted of CTX, ADM and VCR for one cycle, and CDDP and VP-16 for another cycle, were performed and the responses of the tumor were evaluated 4 weeks after the final cycle. Radiotherapy was done after the chemotherapy and the responses were again evaluated 4 weeks after the therapy. Tx, therapy.

b) The number of colonies was counted 3 weeks after the plating of OS1 and OS3, or 4 weeks after that of OS2.

c) Drug concentration was one-tenth of the peak plasma concentration; 4-OOH-CTX was given at 0.4 $\mu \mathrm{g} / \mathrm{ml}$; ADM, at $0.04 \mu \mathrm{g} / \mathrm{ml}$; VCR, at $0.001 \mu \mathrm{g} / \mathrm{ml}$; CDDP, at $0.2 \mu \mathrm{g} / \mathrm{ml}$; and VP-16, at $0.1 \mu \mathrm{g} / \mathrm{ml}$. 


\section{DISCUSSION}

Many SCLC cell lines are available at present. However, it is quite difficult to establish SCLC cell lines from untreated primary tumors and only a few such cell lines have been reported. ${ }^{6,7,12)}$ SCLC often forms visible endobronchial tumors in large bronchi, which can be easily biopsied through a bronchofiberscope without any serious complications. ${ }^{35)}$ If such tiny specimens are enough to produce SCLC cell lines, untreated primary tumors will be usable for the establishment of cell lines and such cell lines will facilitate studies on the following important problems. First, mechanisms of drug resistance could be analyzed by comparing cell lines derived from untreated and treated tumors in the same patient. The most important advantage of bronchofiberscopic biopsy is the ability to obtain tumor specimens serially without difficulty. ${ }^{12)}$ SCLC often relapses at the same site after complete regression. All 4 cell lines presented in this study were derived from untreated tumors and recently we successfully established another SCLC cell line (OS2-relapse) from the primary tumor of Patient $\# 1$ after chemoradiotherapy, and a comparative study of the cell lines (OS2 and OS2-relapse) is under way. Second, the genetic and biologic characteristics of primary and secondary tumor cells from the same person could be easily compared. Third, the study of early-staged SCLC will be possible. Three out of 4 cell lines were derived from patients with LD in this study.

Methods for the establishment of SCLC cell lines using bronchofiberscopic biopsy were simple, but even half a year was not enough time. Although some researchers have discarded cultures with no growth after 3 to 6 months, ${ }^{2,7,11)} 3$ cell lines (except OS3) were established after more than 6 months. SCLC cells may have been dormant, with a subthreshold number of cells in vitro. ${ }^{36}$ ) The other point was to obtain vivid specimens as far as possible. We usually tried to get at least 4 specimens (2 for pathological examination and 2 for culture) when there was no problem such as massive bleeding. Postmus et al. ${ }^{13)}$ established SCLC cell lines from specimens taken with a rigid bronchoscope under general anesthesia, but their cell lines were derived from pre-treated tumors. To study the natural resistance of SCLC, SCLC cell lines from untreated tumors are necessary and diagnostic bronchofiberscopy is useful. General anesthesia is not necessary for the bronchofiberscopic examination.

The success rate for establishment of SCLC was $30 \%$. If many fresh specimens had been obtained, it might have become as high as about $70 \%$, as Carney et al. reported. ${ }^{6)}$ We did not try to heterotransplant biopsied specimens into nude mice for the establishment of cell lines because type- $\mathrm{C}$ virus of mouse origin was often integrated into the human genome of heterotransplanted tumors. $^{37)}$

The characteristics of the 3 cell lines reflected the heterogeneity of SCLC (Table II) and seemed to be related to the clinical responses of the respective tumors. To analyze further the association, clonogenic assay was carried out for chemo-radiosensitivity of the SCLC cell lines. A good correlation between clinical responses and chemo-radiosensitivity was found (Table III). Since our cell lines were derived from untreated primary tumors, this suggests that SCLC might be predisposed to have diverse sensitivity to chemo-radiotherapy, although cancer cells surviving the therapy become more resistant. OS1 and OS3 were naturally resistant to all drugs tested, while OS2 was sensitive. This could not be explained in terms of multidrug resistance gene ( $m d r 1$ ), because this gene seemed to be associated with resistance only to heterocyclic compounds. Amplification of $m d r 1$ or its enhanced expression has never been reported in SCLC. ${ }^{38)}$ The multidrug resistance of OS1 and OS3 should be due to other mechanisms. On the other hand, the clinical development of chemo-radioresistance may be shown in vitro by using a sensitive line, OS2. OS 3 was resistant to drugs but partially sensitive to irradiation, which suggested that the mechanisms of natural resistance to drugs may be different from that of radioresistance, as Carney et al. reported. ${ }^{16)}$

In conclusion, we have successfully established new SCLC cell lines. All of them were derived from untreated primary tumors biopsied by diagnostic bronchofiberscopy. The success rate for establishment was $4 / 13$ $(30 \%)$. The morphological, biologic, biochemical and genetic characteristics of the 3 cell lines were quite different, in agreement with the heterogeneity of SCLC. Their chemo-radiosensitivity was also variable and well correlated with the clinical responses of the respective tumors. Mechanisms mediating natural or acquired resistance to chemo-radiotherapy of SCLC may be elucidated by using our SCLC cell lines.

\section{ACKNOWLEDGMENTS}

We thank Miss A. Yamane for her technical assistance, Drs. Y. Miyake and K. Yamaguchi for the measurement of GRP, Drs. S. Hosoe and B. Zbar for Southern blot analysis of 3p deletion, and Drs. T. Kameya and S. Shimosato for discussions in the field of pathology. This study was supported by a Grant-in-Aid for Cancer Research from the Ministry of Health and Welfare.

(Received October 13, 1989/Accepted January 18, 1990) 


\section{REFERENCES}

1) Oboshi, S., Tsugawa, S., Seido, T., Shimosato, Y., Koide, T. and Ishikawa, S. A new floating cell line derived from human pulmonary carcinoma of oat cell type. Gann, 62, 505-514 (1971).

2) Pettengill, O. S., Sorenson, G. D., Wurster-Hill, D. H., Curphey, T. J., Noll, W. W., Cate, C. C. and Maurer, L. H. Isolation and growth characteristics of continuous cell lines from small-cell carcinoma of the lung. Cancer, 45, 906-918 (1980).

3) Gazdar, A. F., Carney, D. N., Russell, E. K., Sims, H. L., Baylin, S. B., Bunn, P. A., Guccion, J. G. and Minna, J. D. Establishment of continuous, clonable cultures of smallcell carcinoma of the lung which have amine precursor uptake and decarboxylation cell properties. Cancer Res., 40, 3502-3507 (1980).

4) Simms, E., Gazdar, A. F., Abrams, P. G. and Minna, J. D. Growth of human small cell (oat cell) carcinoma of the lung in serum-free growth factor-supplemented medium. Cancer Res., 40, 4356-4363 (1980).

5) Carney, D. N., Bunn, P. A., Jr., Gazdar, A. F., Pagan, J. A. and Minna, J. D. Selective growth in serum-free hormone-supplemented medium of tumor cells obtained by biopsy from patients with small cell carcinoma of the lung. Proc. Natl. Acad. Sci. USA, 78, 3185-3189 (1981).

6) Carney, D. N., Broder, L., Edelstein, M., Gazder, A. F., Hansen, M., Havemann, K., Matthews, M. J., Sorenson, G. D. and Videlov, L. Experimental studies of the biology of human small cell lung cancer. Cancer Treat. Rep., 67, 27-35 (1983).

7) Carney, D. N., Gazdar, A. F., Bepler, G., Guccion, J. G., Marangos, P. J., Moody, T. W., Zweig, M. H. and Minna, J. D. Establishment and identification of small cell lung cancer cell lines having classic and variant features. Cancer Res., 45, 2913-2923 (1985).

8) Gazdar, A. F., Carney, D. N., Nau, M. M. and Minna, J. D. Characterization of variant subclasses of cell lines derived from small cell lung cancer having distinctive biochemical, morphological, and growth properties. Cancer Res., 45, 2924-2930 (1985).

9) Broers, J. L. V., Carney, D. N., de Ley, L., Vooijs, G. P. and Ramaekers, F. C. S. Differential expression of intermediate filament proteins distinguishes classic from variant small-cell lung cancer cell lines. Proc. Natl. Acad. Sci. USA, 82, 4409-4413 (1985).

10) de Leij, L., Postmus, P. E., Buys, C. H. C. M., Elema, J. D., Ramaekers, F., Roppema, S., Brouwer, M., van der Veen, A. Y., Mesander, G. and The, T. H. Characterization of three new variant type cell lines derived from small cell carcinoma of the lung. Cancer Res., 45, 6024-6033 (1985).

11) Duchesne, G. M., Eady, J. J., Peacock, J. H. and Pera, M. F. A panel of human lung carcinoma lines: establishment, properties and common characteristics. Br. J. Cancer, 56, 287-293 (1987).
12) Berendsen, H. H., de Leij, L., de Vries, E. G. E., Mesander, G., Mulder, N. H., de Jong, B., Buys, C. H. C. M., Postmus, P. E., Poppema, S., Sluiter, H. J. and The, H. T. Characterization of three small cell lung cancer cell lines established from one patient during longitudinal follow-up. Cancer Res., 48, 6891-6899 (1988).

13) Postmus, P. E., de Ley, L., van der Veen, A. Y., Mesander, G., Buys, C. H. C. M. and Elema, J. D. Two small cell lung cancer cell lines established from rigid bronchoscope biopsies. Eur. J. Cancer Clin. Oncol., 24, 753-763 (1988).

14) Bepler, G., Jaques, G., Havemann, K., Koehler, A., Johnson, B. E. and Gazdar, A. F. Characterization of two cell lines with distinct phenotypes established from a patient with small cell lung cancer. Cancer Res., 47, 1883-1891 (1987).

15) Abeloff, M. D., Eggleston, J. C., Mendelsohn, G., Ettinger, D. S. and Baylin, S. B. Changes in morphologic and biochemical characteristics of small cell carcinoma of the lung: a clinicopathologic study. Am. J. Med., 66, 757764 (1979)

16) Carney, D. N., Mitchell, J. B. and Kinsella, T. J. In vitro radiation and chemotherapy sensitivity of established cell lines of human small cell lung cancer and its large cell morphological variants. Cancer Res., 43, 2806-2811 (1983).

17) Sehested, M., Hirsch, F. R., Osterlind, K. and Olsen, J. E. Morphologic variations of small cell lung cancer. A histopathologic study of pretreatment and posttreatment specimens in 104 patients. Cancer, 57, 804-807 (1986).

18) Nicolson, G. L. Tumor cell instability, diversification, and progression to the metastatic phenotype: from oncogene to oncofetal expression. Cancer Res., 47, 1473-1487 (1987).

19) Oyama, V. I. and Eagle, H. Measurement of cell growth in tissue culture with a phenol reagent (Folin-Ciocalteau). Proc. Soc. Exp. Biol. Med., 91, 305-307 (1956).

20) Carney, D. N., Marangos, P. J., Ihde, D. C., Bunn, P. A., Cohen, M. H., Minna, J. D. and Gazdar, A. F. Serum neuron-specific enolase: a marker for disease extent and response to therapy of small-cell lung cancer. Lancet, $\mathbf{i}$, 583-585 (1982).

21) Wong, R. and Swallen, T. O. Cellulose acetate electrophoresis of creatine phosphokinase isoenzymes in the diagnosis of myocardial infarction. Am. J. Clin. Pathol., 64, 209-216 (1975).

22) Yamaguchi, K., Abe, K., Kameya,T., Adachi, I., Taguchi, S., Otsubo, K. and Yanaihara, N. Production and molecular size heterogeneity of immunoreactive gastrinreleasing peptide in fetal and adult lungs and primary lung tumors. Cancer Res., 43, 3932-3939 (1983).

23) Tanio, Y., Talmadge, C., Dekaban, G., Hovis, J., Ohanian, S. H. and Zbar, B. In vivo immunologic selection of proviral gene deletion variants from a nonproducer clone. J. Natl. Cancer Inst., 77, 767-775 (1986). 
24) Southern, E. M. Detection of specific sequences among DNA fragments separated by gel electrophoresis. $J . \mathrm{Mol}$. Biol., 98, 503-517 (1975).

25) Taya, Y., Hosogai, K., Hirohashi, S., Shimosato, Y., Tsuchiya, R., Tsuchida, N., Fushimi, M., Sekiya, T. and Nishimura, S. A novel combination of K-ras and myc amplification accompanied by point mutational activation of K-ras in a human lung cancer. EMBO J., 3, 2943-2946 (1984).

26) Kohl, N. E., Kanda, N., Schreck, R. R., Bruns, G., Latt, S. A., Gilbert, F. and Alt, F. W. Transposition and amplification of oncogene-related sequences in human neuroblastomas. Cell, 35, 359-367 (1983).

27) Nau, M. M., Brooks, B. J., Battey, J., Sausville, E., Gazdar, A. F., Kirsch, I. R., McBride, O. W., Bertness, V., Hollis, G. F. and Minna, J. D. L-myc, a new mycrelated gene amplified and expressed in human small cell lung cancer. Nature, 318, 69-73 (1985).

28) Erikson, J., Finan, J., Nowell, P. C. and Croce, C. M. Translocation of immunoglobulin $\mathrm{V}_{\mathrm{H}}$ genes in Burkitt lymphoma. Proc. Natl. Acad. Sci. USA, 79, 5611-5615 (1982).

29) Hamburger, A. W. and Salmon, S. E. Primary bioassay of human tumor stem cells. Science, 197, 461-463 (1977).

30) Salmon, S. E., Hamburger, A. W., Soehnlen, B., Durie, B. G. M., Alberts, D. S. and Moon, T. E. Quantitation of differential sensitivity of human-tumor stem cells to anticancer drugs. N. Engl. J. Med., 298, 1321-1327 (1978).

31) Souhami, R. L., Beverley, P. C. L. and Bobrow, L. G. Antigens of small-cell lung cancer: First International Workshop. Lancet, ii, 325-326 (1987).
32) Kawase, I., Komuta, K., Ogura, T., Fujiwara, H., Hamaoka, T. and Kishimoto, S. Murine tumor cell lysis by antibody-dependent macrophage-mediated cytotoxicity using syngeneic monoclonal antibodies. Cancer Res., 45, 1663-1668 (1985).

33) Little, C. D., Nau, M. M., Carney, D. N., Gazdar, A. F. and Minna, J. D. Amplification and expression of the c-myc oncogene in human lung cancer cell lines. Nature, 306, 194-196 (1983).

34) Nau, M. M., Brooks, B. J., Carney, D. N., Gazdar, A. F., Battey, J. F., Sausville, E. A. and Minna, J. D. Human small-cell lung cancers show amplification and expression of the N-myc gene. Proc. Natl. Acad. Sci. USA, 83, 10921096 (1986).

35) Martini, N. and McCormick, P. M. Assessment of endoscopically visible bronchial carcinomas. Chest, 73, 718720 (1978).

36) Sugarbaker, E. V., Ketcham, A. S. and Cohen, A. M. Studies of dormant tumor cells. Cancer, 28, 545-552 (1971).

37) Suzuki, T., Yanagihara, K., Yoshida, K., Seido, T., Kuga, N., Shimosato, Y. and Oboshi, S. Infectious murine type-C viruses released from human cancer cells transplanted into nude mice. Gann, 68, 99-106 (1977).

38) Goldstein, L. J., Galski, H., Fojo, A., Willingham, M., Lai, S-L., Gazdar, A., Pirker, R., Green, A., Crist, W., Brodeur, G. M., Lieber, M., Cossman, J., Gottesman, M. M. and Pastan, I. Expression of a multidrug resistance gene in human cancers. J. Natl. Cancer Inst., 81, 116-124 (1989). 